\title{
Schistosomiasis: an epidemiological update on Brazil's southernmost low endemic area in Esteio
}

\author{
Angélica da Paz Ramírez ${ }^{[1] *}$, Vivian Favero[1], Catieli Gobetti Lindholz ${ }^{[1]}$, \\ Carolina de Marco Veríssimo ${ }^{[1]}$, Vanessa Fey Pascoa [1], Renata Russo Frasca Candido ${ }^{[1],[2],}$ \\ Alessandra Loureiro Morassutti ${ }^{[1]}$, Carlos Graeff-Teixeira ${ }^{[1],[3]}$
}

\author{
[1]. Pontifícia Universidade Católica do Rio Grande do Sul, Escola de Ciências, \\ Departamento de Ecologia e Biodiversidade, Porto Alegre, RS, Brasil. \\ [2]. University of Western Australia, Department of Physics, Perth, Australia. \\ [3]. Universidade Federal do Espírito Santo, Centro de Ciências da Saúde, \\ Departamento de Patologia e Núcleo de Doenças Infecciosas, Vitória, ES, Brasil.
}

\begin{abstract}
Introduction: Brazil's southernmost state, Rio Grande do Sul (RGS), was considered schistosomiasis-free until 1998 when a low endemic focus was identified in Esteio, a city located next to the capital of RGS. In the last two decades, the control interventions applied in the region have been apparently successful, and the absence of new cases indicated the possibility of interrupted schistosomiasis transmission. The objective of this study was to update the clinical and epidemiological data of schistosomiasis in Esteio. Methods: We reviewed all 28 individuals diagnosed with the infection since 1997 and a survey was applied to a group of 29 school-aged children residing in Vila Pedreira, one of the most affected neighborhoods. Results: No eggs were detected in fecal samples using the Helmintex method, and all samples were negative for serum antibodies on examination by the western blot technique using the Schistosoma mansoni microsomal antigen (MAMAWB). In contrast, 23 individuals (79\%) tested positive for the cathodic circulating antigen with the point-of-care immunochromatographic test (POC-CCA) on urine samples. Of the 28 formerly infected individuals, only eight were located, of which four tested positive, and four tested negative for serum antibodies using the MAMA-WB technique. Conclusions: Current adverse conditions for $S$. mansoni transmission in Esteio and the absence of a confirmed diagnosis suggests that there is (i) a lack of specificity of the POC-CCA test in low endemic settings, and (ii) a high probability that interruption of schistosomiasis has been achieved in Esteio.
\end{abstract}

Keywords: Schistosomiasis. POC-CCA. Helmintex. MAMA. Esteio. Low endemicity.

\section{INTRODUCTION}

The areas in Brazil endemic for schistosomiasis infection include six northeastern states, the southeastern state of Minas Gerais, and 12 additional states that were found to be the focus of transmission ${ }^{1,2}$. Located next to the border with Uruguay and Argentina, the state of Rio Grande do Sul (RGS) has been considered schistosomiasisfree; however, the autochthonous transmission of the parasite was confirmed in 1998 after the identification of infected snails at two sites next to the Sinos River in Esteio ${ }^{3}$. Biomphalaria glabrata snails were first documented in Esteio in 1997 after schistosomiasis was diagnosed in an adult male hospitalized with hepatitis. However, the occurrence of autochthonous infection was not confirmed ${ }^{4}$.

\footnotetext{
*In memorian.

Corresponding author: Carlos Graeff-Teixeira.

e-mail: graeff.teixeira@gmail.com

(iD https://orcid.org/0000-0003-2725-0061

Received 27 June 2020

Accepted 31 July 2020
}

The presence of active transmission was documented a year later after the identification of snails infected with Schistosoma mansoni ${ }^{3}$, concurrent with the detection of a second individual diagnosed with schistosomiasis. In this study, we aimed to update the epidemiological data for the transmission of schistosomiasis and tested the hypothesis of transmission interruption in Esteio (RGS).

\section{METHODS}

Study areas and populations

The municipality of Esteio $\left(29^{\circ} 51^{\prime} \mathrm{S}, 51^{\circ} 10^{\prime} \mathrm{W}\right)$ is located in the metropolitan region of Porto Alegre, the capital of Brazil's southernmost state, RGS. The town of Esteio, which had an estimated population of 84,114 in the year 2016, is located alongside the Federal Road BR-116, in a north-south direction, to the eastern side of the highway ${ }^{5}$. The Sinos River runs in a northsouth direction, where infected B. glabrata specimens were found in the swampy plains along the riverside in the following sites: (1) 
Banhado do Azeite (BA); (2) Valo da Três Portos (VTP); and (3) Casa dos Trilhos (CT). The site CT was an isolated shallow pond next to the Siderúrgica Riograndense railway, and snails were not detected at this location after the initial findings in $1999^{6}$. At the site Fazenda Kroeff (FK), there were indications for transmission, and snails were found, though the presence of S.mansoni in snails was never documented. VTP was the only area where people living next to the breeding sites of snails with active transmission last documented in 2011. Infected individuals were residents of the VTP, Novo Esteio (NE), and Vila Pedreira (VP) neighborhoods, where most of the individuals that were initially infected lived (Table 1).

\section{Collection of biological samples for the epidemiological survey at VP}

Fecal, urine, and serum samples were collected from 29 asymptomatic school-aged children (aged 6 to 9 years) from the Centro Municipal de Educação Basica Trindade (Municipal Center for Basic Education Trindade), a community school in VP, between November to December 2015. The children examined had no history of travel to endemic areas or exposure to transmission sites near the Sinos River. The urine and blood samples were collected on a single day at school, and students were given instructions to collect their stools at home and bring it back to the school. Before the collection of biological material from the students, several activities were pursued in the classroom at the community school, including playing games, watching videos, observing live snails, viewing parasitic structures using the microscope, and having educational discussions about health and other issues.

\section{Follow-up investigation of previously infected individuals}

A search for previously infected individuals was performed by visiting their homes at the addresses registered when the patient was documented as being infected. Queries regarding the status of their general health and risky behavior were put to them. For individuals who had relocated, the neighbors/relatives were asked for the new addresses. Additionally, we reviewed the files at the Laboratory of Parasite Biology at The Pontifical Catholic University of RGS to summarize and update the information related to the tests performed for the infected individuals in Esteio.

\section{Enzyme-linked immunoelectrotransfer blot}

Approximately $5 \mathrm{~mL}$ of blood was collected via venipuncture under aseptic conditions and transferred to $15 \mathrm{~mL}$ centrifuge tubes for the separation of serum on the same day. Serum samples were stored at $-80^{\circ} \mathrm{C}$ for further use. Strips containing S. mansoni microsomal antigen (MAMA) and the protocol for western blot were obtained from the Centers for Disease Control and Prevention, $\mathrm{USA}^{7,8}$. Test sera were diluted 1:100 in PBS containing 0.3\% Tween 20 (Sigma-Aldrich, USA) and 5\% nonfat milk powder (Nestlé, Brazil) and incubated with the strips for $1 \mathrm{~h}$ at room temperature (RT) with agitation. After 4 washes with $0.3 \%$ Tween-PBS, the strips were incubated with anti-human IgG coupled to peroxidase for $1 \mathrm{~h}$ at RT, given 4 washes with $0.3 \%$ Tween-PBS, and were subsequently developed using 3,3'-Diaminobenzidine (Sigma-Aldrich, USA). Positive and negative control sera were included for each batch of strips.

\section{Detection of antigen in urine}

Urine samples collected in VP were refrigerated and tested in the laboratory on the same day. Point-of-care circulating cathodic antigen test (POC-CCA; Rapid Medical Diagnostics, Pretoria, South Africa; lot number: 50182, expiry date: 2017/10) was performed as per the manufacturer's instructions. Briefly, one drop of urine was placed in the cassette, followed by a drop of the supplied buffer. After $20 \mathrm{~min}$, three observers independently checked for the presence of the control and test lines. A "trace" was defined as a faint line without clearly defined margins.

\section{The Helmintex method (HTX) for the detection of $S$. mansoni eggs}

The HTX assay was performed according to the technique described by Favero and collaborators ${ }^{9}$. The stool samples (30 g) were fixed in a solution of 5\% Tween-20/70\% ethanol. After fixation and homogenization, the fecal suspension was sieved through a $500 \mu \mathrm{m}$ metal mesh, transferred to a conical flask, and washed until a clear supernatant was obtained. The resulting sediment was further sieved through metal meshes with openings of $150 \mu \mathrm{m}$ and $45 \mu \mathrm{m}$ sequentially, and the latter sieving process was performed to retain the $S$. mansoni eggs. The fraction retained by the last sieve $(45 \mu \mathrm{m})$ was suspended in a $30 \%(\mathrm{v} / \mathrm{v})$ ethyl acetate aqueous solution, homogenized, and centrifuged for $10 \mathrm{~min}$ at $200 \times \mathrm{g}$. After discarding the supernatant and the ring of debris, the pellet was transferred to a microtube containing $19 \mu \mathrm{L}$ of paramagnetic iron oxide particles (Bangs Labs, USA). The microtubes were homogenized by orbital rotation for $30 \mathrm{~min}$ and placed on a magnetic rack (Bangs Labs, USA). After $3 \mathrm{~min}$, the unbound material was discarded before removing the tubes from the rack. The sediment was re-suspended in $100 \mu \mathrm{L}$ of $0.9 \%$ aqueous $\mathrm{NaCl}$ solution and stored at $-4^{\circ} \mathrm{C}$ for further analysis. For microscopy analysis, the sediments were

TABLE 1: Distribution of the dwellings of 28 infected individuals in three neighborhoods: Vila Pedreira (VP), Novo Esteio (NE), and Valo da Três Portos (VTP), between 1997 to 2011, in Esteio, Rio Grande do Sul, Brazil.

\begin{tabular}{|c|c|c|c|c|c|c|c|c|c|c|c|c|c|c|c|}
\hline Local/Year & 97 & 98 & 99 & 00 & 01 & 02 & 03 & 04 & 05 & 06 & 07 & 08 & 09 & 10 & 11 \\
\hline VP & $\bullet \bullet$ & & & $\bullet \bullet$ & & $\bullet$ & $\bullet$ & & & & & & & & \\
\hline $\mathrm{NE}$ & & $\bullet \bullet$ & & $\bullet$ & $\bullet$ & $\bullet$ & $\bullet \bullet$ & & & & & $\bullet$ & & $\bullet$ & \\
\hline VTP & & $\bullet$ & & $\bullet \bullet$ & & & & & & & $\bullet \bullet$ & & $\bullet$ & & $\bullet \bullet \bullet$ \\
\hline
\end{tabular}


stained with 3\% (w/v) ninhydrin (Sigma-Aldrich, USA) in 70\% ethanol and evenly spread over $24 \mu \mathrm{m}$ pore filter paper (UNIFIL, Brazil) of area $5 \times 2.5 \mathrm{~cm}$, provided an ID and kept for examination by optical microscopy (100× magnification).

\section{Ethical considerations}

The research was conducted according to Brazilian regulations and conformed to the principles outlined in the Declaration of Helsinki of 1964 as revised in 2000. The study protocol was approved by the Research Ethics Committee of PUCRS (CAAE 18944614.3.0000.5336).

\section{RESULTS}

\section{Evaluation of formerly infected individuals}

Between 1997 and 2000, 11 infected individuals from Esteio were diagnosed as having schistosomiasis ${ }^{6}$, and an additional 17 individuals were found to be infected between 2001 and 2011 (Table 1). An updated summary of the clinical and epidemiological data for the 28 infected individuals is presented in Table 2. The patients were living in three neighborhoods: VP, NE, and VTP, at the time of diagnosis. Table 3 summarizes the information on the updated (2015) dwellings of the patients; information for 10

TABLE 2: Summary of the original and updated clinical and epidemiological data for the 28 infected individuals from Esteio, Rio Grande do Sul, Brazil, who were infected between 1997 to 2011 .

\begin{tabular}{|c|c|c|c|c|c|}
\hline \multirow[b]{2}{*}{$\operatorname{ld}^{*}$} & \multirow[b]{2}{*}{ Date } & \multirow[b]{2}{*}{ Initial clinico-epidemiological situation } & \multirow[b]{2}{*}{ Neighborhoods } & \multicolumn{2}{|c|}{ Follow-up in 2015} \\
\hline & & & & WB-MAMA & $\begin{array}{l}\text { Clinical - } \\
\text { epidemiological } \\
\text { situation }\end{array}$ \\
\hline 1 & January 1997 & hepatitis, admitted to the local Hospital & Vila Pedreira & Positive & Asymptomatic \\
\hline 2 & October 1997 & positive in parasitological survey & Vila Pedreira & Negative & Asymptomatic \\
\hline 3 & October 1998 & urticaria, outpatient clinic & Novo Esteio & - & $\begin{array}{l}\text { Moved, outbound } \\
\text { Esteio }\end{array}$ \\
\hline 4 & October 1998 & sharing risk behavior with patient 3 (BA) & Novo Esteio & - & Not found \\
\hline 5 & October 1998 & sharing risk behavior with patient 3 (BA) & Novo Esteio & - & $\begin{array}{l}\text { Moved, outbound } \\
\text { Esteio }\end{array}$ \\
\hline 6 & October 1998 & positive in parasitological survey & VTP $^{* *}$ & - & Not found \\
\hline 7 & May 2000 & positive in parasitological survey & Vila Pedreira & Positive & Asymptomatic \\
\hline 8 & May 2000 & positive in parasitological survey & Vila Pedreira & - & Not found \\
\hline 9 & July 2000 & Abdominal pain & VTP & - & Not found \\
\hline 10 & October 2000 & positive in parasitological survey & VTP & Positive & Asymptomatic \\
\hline 11 & October 2000 & positive in parasitological survey & Novo Esteio & - & Not found \\
\hline 12 & October 2002 & positive in serological survey, confirmed parasitologically & Novo Esteio & - & $\begin{array}{l}\text { Moved to Montenegro, } \\
\text { RS. Outbound Esteio }\end{array}$ \\
\hline 13 & October 2002 & positive in serological survey, confirmed parasitologically & Vila Pedreira & - & $\begin{array}{l}\text { Death, not related to } \\
\text { schistosomiasis }\end{array}$ \\
\hline 14 & January 2003 & positive in serological survey, confirmed parasitologically & Vila Pedreira & & $\begin{array}{l}\text { Moved to Canoas, RS. } \\
\text { Outbound Esteio }\end{array}$ \\
\hline 15 & June 2003 & positive in serological survey, confirmed parasitologically & Novo Esteio & - & $\begin{array}{l}\text { Moved to Imbé, RS. } \\
\text { Outbound Esteio }\end{array}$ \\
\hline 16 & Jullho 2003 & positive in serological survey, confirmed parasitologically & Novo Esteio & Negative & Asymptomatic \\
\hline 17 & Jullho 2003 & positive in serological survey, confirmed parasitologically & Vila Pedreira & Positive & Asymptomatic \\
\hline 18 & June 2001 & positive in serological survey, confirmed parasitologically & Novo Esteio & - & Not found \\
\hline 19 & July 2007 & sharing risk behavior with patient 10 (VTP) & VTP & - & Not found \\
\hline 20 & July 2007 & sharing risk behavior with patient 10 (VTP) & VTP & - & Not found \\
\hline 21 & November 2007 & positive in parasitological survey & VTP & - & Not found \\
\hline 22 & October 2008 & positive in parasitological survey & Novo Esteio & - & Not found \\
\hline 23 & June 2009 & positive in parasitological survey & VTP & - & Not found \\
\hline 24 & June 2009 & positive in parasitological survey & VTP & - & Not found \\
\hline 25 & July 2010 & sharing risk behavior with patient $18(\mathrm{BA})$ & Novo Esteio & & Not found \\
\hline 26 & August 2010 & sharing risk behavior with patient 10 (VTP) & Canoas & Negative & Asymptomatic \\
\hline 27 & November 2010 & sharing risk behavior with patient 10 (VTP) & Canoas & Negative & Asymptomatic \\
\hline 28 & November 2010 & sharing risk behavior with patient 10 (VTP) & Unknown & - & Not found \\
\hline
\end{tabular}

*Id: identification code; ${ }^{* *}$ VTP: Valo da Três Portos neighborhood. 
TABLE 3: Updated (2015) information for the dwellings of the 28 individuals from Esteio, RS, Brazil who were infected with schistosomiasis between 1997 to 2011.

\begin{tabular}{lc}
\hline Information on residence & Number \\
\hline Known & Number \\
Not moved & 5 \\
Moved, outbounds Esteio & 12 \\
Moved, inbounds Esteio & 18 \\
Unknown & 12 \\
\hline Totals & 18 \\
\hline
\end{tabular}

individuals was not available, 5 were living in the same place, and 13 individuals had moved from their original place of residence (1 had moved within, and 12 had relocated out of Esteio). Serum samples for follow-up experiments were collected from 8 formerly infected individuals, of which four each tested positive and negative using the MAMA-WB assay. No other method was used for the examination of these individuals.

\section{School-aged children}

Samples for urine, blood, and/or feces were collected from 29 children aged between 6 and 9 years (average $7.13 \pm 0.97$ yrs.), who had a gender distribution of 55\% male and $45 \%$ female children. HTX and MAMA-WB assays were not performed on every sample because a few children showed resistance to submitting blood or feces, or both. Seven children provided only fecal and urine samples, while 16 children provided blood and urine samples alone (Table 4). No fecal or serum samples were found positive after examination by HTX and/or MAMA-WB assays; however, the POC-CCA urine test results were positive or a trace line was seen in 23 out of 29 samples (79.3\%). Trace results for the POC-CCA test were observed in 8 of the 23 positive samples (considered as positive CCA detection, according to the manufacturer's instructions), and 6 of the total 29 samples were CCA-negative (Table 4).

\section{DISCUSSION}

The focus of schistosomiasis transmission in Esteio has several peculiar characteristics. First, B. glabrata snails have never been detected in Brazil's southernmost state, $\operatorname{RGS}^{4,10}$, and these have probably been recently introduced in Esteio by fishermen to be used as baits, as suggested by several residents. Endemic areas in the northern state of Paraná, 1,100 km away from Esteio, have been the southern limit for the occurrence of B. glabrata in Brazil ${ }^{1}$. Second, swampy sites with infected snails were found to be sharply delimited next to the Sinos River and were located at some distance from the urbanized neighborhoods, especially in NE, west of BR116 road, which had 5,000 inhabitants. In VTP, a small number of families lived next to an old man-made channel ("valo") to pump water from the river to a nearby cellulose industry named "Três Portos". Between 1997 to 2011, the VTP area alone had overlapping houses and transmission sites before environmental changes and population reduction occurred, as described below. The Vila Pedreira neighborhood located immediately to the east
TABLE 4: A comparison of the results from three diagnostic methods: point-of-care immunochromatographic detection of circulating cathodic antigen (POC-CCA), Western-blot with microsomal Schistosoma mansoni antigen (WB-MAMA) and Helmintex for egg detection in feces. The data are from 29 school-aged children from Vila Pedreira, Esteio, Brazil, 2015.

\begin{tabular}{|c|c|c|c|}
\hline Sample & POC-CCA & WB-MAMA & Helmintex \\
\hline 1 & Positive & Negative & Negative \\
\hline 4 & Positive & Negative & Negative \\
\hline 6 & Positive & Negative & Negative \\
\hline 19 & Positive & Negative & Negative \\
\hline 20 & Positive & Negative & Negative \\
\hline 17 & Positive & Negative & - \\
\hline 26 & Positive & Negative & - \\
\hline 28 & Positive & Negative & - \\
\hline 5 & Positive & - & Negative \\
\hline 9 & Positive & - & Negative \\
\hline 12 & Positive & - & Negative \\
\hline 13 & Positive & - & Negative \\
\hline 21 & Positive & - & Negative \\
\hline 22 & Positive & - & Negative \\
\hline 27 & Positive & - & Negative \\
\hline 7 & Trace & Negative & - \\
\hline 8 & Trace & Negative & - \\
\hline 11 & Trace & Negative & - \\
\hline 14 & Trace & Negative & - \\
\hline 16 & Trace & Negative & - \\
\hline 23 & Trace & Negative & - \\
\hline 24 & Trace & Negative & - \\
\hline 29 & Trace & Negative & Negative \\
\hline 2 & Negative & Negative & - \\
\hline 3 & Negative & Negative & - \\
\hline 10 & Negative & Negative & - \\
\hline 15 & Negative & Negative & - \\
\hline 18 & Negative & Negative & - \\
\hline 25 & Negative & Negative & - \\
\hline
\end{tabular}

of the BR-116 road had 1,500 inhabitants and also had infected individuals. In Esteio, except for the inhabitants of VTP, exposure to $S$. mansoni infection may have been hindered by the long distances which require travel on foot, which may partially explain the ultra-low endemicity observed for more than two decades. Positivity rates were observed to be below $0.13 \%$ in surveys from 1997 to $2000^{6}$. As indicated in Table 1, most of the infected individuals initially resided in VP, and in 2011, most of the infected individuals were from VTP. 
The main transmission site was found to be Banhado do Azeite (BA), an approximately $48,000 \mathrm{~m}^{2}$ grassy shallow swamp on the left margin of the Sinos River. It was a popular fishing location used mainly by adults and young males, who commonly used snails as bait. People from the NE and VP communities, and others, reported that the areas next to the Sinos River were considered unsafe because of violence and activities related to drugs, as the river is used as an escape route to hide. Environmental modification has also contributed to the reduced transmission in BA and VTP. Since 2003, successful drainage treatment has prevented the land in BA from holding water, and consequently, it remains mostly dry. The occurrence of transmission was documented in VTP until 2011, but the construction of BR-448 road (between 2011 to 2013) affected the area, reducing its water content. All residents relocated from VTP after several conflicts, and a new owner started earthworks to build a warehouse. Thus, a combination of the geographic characteristics, environmental changes, and cultural-educational factors contributed to the decline in the transmission of schistosomiasis in Esteio.

Further, based on the information provided by the children, their parents, and relatives, a striking change in behavior was observed concerning exposure to transmission sites next to the Sinos River, although these anecdotes were not part of the systematized data gathering procedure. The School Trindade in VP has made continuous efforts to build awareness in children and the community about behavioral risks and prejudices related to schistosomiasis. This would partly explain the negative results obtained from the serological and HTX assays in the 6 to 9 yr age group. Positivity rates in school-aged children (SAC) are usually a good indicator of the prevalence of schistosomiasis in the community at large. Further, testing SAC can be used to infer active transmission, and help avoid false-positive results from chronically infected, albeit cured adult individuals ${ }^{11}$. Additionally, this group is a priority target for control interventions ${ }^{12}$.

The MAMA assay was employed for the detection of antibodies and it has an estimated sensitivity and specificity of $99 \%{ }^{13,14}$. Microsomal antigens, including those for other Schistosoma species such as S. japonicum (JAMA) and S. haematobium (HAMA), are useful for monitoring the prevalence of the disease, especially in areas of low endemicity ${ }^{15,16}$. Further, serum antibodies are longlasting and can give positive results in patients who no longer carry the infection ${ }^{17}$.

Helmintex is a new egg-detection reference method for the identification of true-positive schistosomiasis-infected individuals. It has a $100 \%$ sensitivity for egg burdens higher than 1.3 eggs per gram of feces ${ }^{18}$, and is based on the isolation of eggs from a large volume of feces through their interaction with paramagnetic particles that can be recovered using a magnetic field ${ }^{9,19}$.

Antigen detection in urine is a promising alternative as a screening tool for the Kato-Katz method in areas with high endemicity ${ }^{20,21}$. In contrast, the performance of POC-CCA may be unreliable in low endemicity areas ${ }^{22-25}$. In our study, we obtained positive results from the POC-CCA test in 79.3\% samples, with no corresponding positive results from the MAMA-WB and HTX assays, suggest that the test has potential specificity limitations. The confirmation of false-positives in the POC-CCA test requires the study of larger groups and the daily repetition of the HTX assay. However, this was not possible in 2015 due to operational difficulties resulting from the socially problematic settings in these areas. The low specificity of $35.5 \%$ was estimated for the POC-CCA test in a large population in the endemic area of southern Sergipe in Brazil ${ }^{24}$. Specificities for the POC-CCA test were evaluated to be higher in non-endemic areas in Tanzania (86.7\%), Ethiopia (99\%), and Ecuador $(100 \%)^{26-28}$. Coelho and collaborators have demonstrated the inaccuracy of the "trace" results obtained using the POC-CCA test (considered as positive per the manufacturer's instructions): after lyophilization, samples that previously showed ambiguous results in the POC-CCA test were found to be either positives or negatives $^{29}$. The cost of such an improvement in the interpretation of results is the loss of the intended "point-of-care" character of the test ${ }^{23}$. The discrepancies in the accuracy of different batches of POC-CCA kits require resolution before additional extensive evaluations lead to the detection of antigen consistently and reproducibly in urine, especially in areas with low endemicity ${ }^{22,23,30}$.

In this study, the mobility of the population living next to the Sinos River schistosomiasis focus (Table 3) prevented the close follow-up of infected individuals by public health agents or research groups. For many individuals from the area, changing their address, and concealing information is part of a strategy to cope with socioeconomic problems. However, although mobility can increase the probability of schistosomiasis spread, it may involve distancing from the transmission sites. Moreover, the active role played by community health agents (agentes comunitários de saúde) has considerably reduced and prevented the spread of schistosomiasis through the evaluation of risk behavior, providing immediate treatment, and close follow-ups.

In this study, there were difficulties in obtaining biological material, especially feces. This was a major drawback in many surveys undertaken in Esteio for two decades. In contrast, obtaining urine samples is much easier; and these can be obtained immediately after the first contact with households or at gatherings like the one established at the Trindade School for this study. However, the poor performance and reproducibility of the POC-CCA detection method is an important concern for its implementation as a routine screening procedure, especially in areas such as Esteio that have low endemicity $23,25,30$.

To conclude, there are indications that schistosomiasis transmission has been interrupted in Esteio, though the confirmation of this observation requires long-term monitoring. However, it is challenging to avoid a tendency to neglect epidemiological vigilance for a health problem that does not translate into a detectable disease. The current situation described in Esteio indicates a case of successful schistosomiasis control, that contributes to the national and global efforts of the Brazilian Ministry of Health, the PanAmerican Health Organization, and the World Health Organization in containing the spread of schistosomiasis ${ }^{12,31}$.

\section{ACKNOWLEDGMENTS}

We acknowledge the support of the entire staff at the Vila Pedreira School, Centro Municipal de Educação Básica Trindade, and especially of Dilara Maria Acosta and the headmaster Marcelo Ohlweiler. We thank Elsa Sinara Both, Daiane de Oliveira 
Garcia (community health agents), Maria Ceci Salcedo Botelho (schistosomiasis control manager), and the entire staff at the Public Health Authority of Esteio. Special thanks are due to the children, their families, and the communities at Vila Pedreira, Novo Esteio, Valo da Três Portos (Seu Remy and family), and other neighborhoods. John Noh and Sukwan Handali, from the Centers for Disease Control and Prevention, USA kindly provided the MAMA antigen and suggestions related to the study.

\section{AUTHOR CONTRIBUTIONS}

APR: study conception and design, and data acquisition, analysis, and interpretation; VF: data acquisition, analysis, and interpretation, and the critical revision and final approval of the version of the manuscript to be submitted; CGL: data acquisition, final approval of the version of the manuscript to be submitted; CDMV: data acquisition, and drafting of the manuscript, it's critical revision, and final approval of the version to be submitted; VFP: data acquisition, analysis, and interpretation, and the final approval of the version of the manuscript to be submitted; RRFC: study conception and design, analysis and interpretation of data, drafting of manuscript; critical revision, and final approval of the version to be submitted; ALM: study conception and design, analysis and interpretation of data, and the critical revision and final approval of the version of the manuscript to be submitted; CGT: study conception and design, analysis and interpretation of data, drafting of the manuscript, and the critical revision and final approval of the version to be submitted.

\section{FINANCIAL SUPPORT}

C.Graeff-Teixeira is recipient of Conselho Nacional de Desenvolvimeto Científico e Tecnológico PQ 1D fellowship and funding: 307005/2014-3.

\section{CONFLICT OF INTEREST}

The authors declare that there is no conflict of interest.

\section{REFERENCES}

1. Brasil. Vigilância da Esquistossomose Mansoni : diretrizes técnicas. 4th Ed., Brasília, Ministério da Saúde, Secretaria de Vigilância em Saúde, Departamento de Vigilância das Doenças Transmissíveis, 2014. 144p. Available 26 May 2020 from: http://bvsms.saude.gov.br/bvs/publicacoes/ vigilancia_esquistossome_mansoni_diretrizes_tecnicas.pdf

2. Katz N. Inquérito nacional de prevalência da esquistossomose mansoni e geo-helmintoses (2010-2015). 1st Ed., Belo Horizonte, Instituto René Rachou (FIOCRUZ), 2018. 76p. Available 26 May 2020 from: https:// www.arca.fiocruz.br/handle/icict/25662

3. Graeff-Teixeira C, Anjos CB, Oliveira VC, Velloso CFP, Fonseca MBS, Valar C, et al. Identification of a transmission focus of Schistosoma mansoni in the southernmost Brazilian State, Rio Grande do Sul. Mem Inst Oswaldo Cruz. 1999;94(1):1-10.

4. Carvalho OS, Nunes IM, Caldeira RL. First report of Biomphalaria glabrata in Rio Grande do Sul, Brazil. Mem Inst Oswaldo Cruz. 1998;93(1):39-40.

5. IBGE. Estimativas populacionais para os municípios e para as Unidades da Federação brasileiros em 01.07.2016. Rio de Janeiro, Instituto Brasileiro de Geografia e Estatística, 2016. Available May 20, 2020 from: ftp://ftp.ibge.gov.br/Estimativas_de_Populacao/Estimativas_2016/ estimativa dou 2016 20160913.pdf
6. Graeff-Teixeira C, Valar C, de Moraes CK, Salvany AM, Brum C de $\mathrm{O}$, Maurer RL, et al. The initial epidemiological studies in the low endemicity schistosomiasis area in Esteio, Rio Grande do Sul, the southernmost Brazilian state, 1997 to 2000 . Mem Inst Oswaldo Cruz. 2004;99(Suppl. I):73-8.

7. Tsang VCW, Wilkins PP. Immunodiagnosis of schistosomiasis. Clin Lab Med. 1991;11:1029.

8. Tsang VCW, Wilkins PP. Immunodiagnosis of Schistosomiasis. Immunol Invest. 1997;26(1-2):175-88.

9. Teles HMS, Pereira PAC, Richinitti LMZ. Distribuição de Biomphalaria (Gastropoda, Planorbidea) nos Estados do Rio Grande do Sul e Santa Catarina, Brasil. Rev Saude Publica. 1991;25(5):350-2.

10. Pereira APB, Favre TC, Galvão AF, Beck L, Barbosa CS, Pieri OS. The prevalence of schistosomiasis in school-aged children as an appropriate indicator of its prevalence in the community. Mem Inst Oswaldo Cruz. 2010;105(4):563-9.

11. World Health Organization (WHO). Schistosomiasis: progress report 2001-2011, strategic plan 2012-2020. Geneva: WHO; 2013. 74p. Available 15 June 2020 from: https://apps.who.int/iris/handle/10665/78074

12. Tsang VCW, Hancock K, Kelly MA, Wilson BC, Maddison SE. Schistosoma mansoni adult microsomal antigens, a serological reagent. II. Specificity of antibody responses do the $S$. mansoni microsomal antigen (MAMA). J Immunol. 1983;130(3):1366-70.

13. Tsang VCW, Peralta, JM, Simons AR. Enzyme-linked immunoelectrotransfer blot techniques (EITB) for studying the specificities of antigens and antibodies separated by gel electrophoresis. Methods Enzymol. 1983;92:377-91.

14. Xu J, Peeling RW, Chen J-X, Wu X-H, Wu Z-D, Wang SP, et al. Evaluation of Immunoassays for the Diagnosis of Schistosoma japonicum Infection Using Archived Sera. PLoS Negl Trop Dis. 2011;5(1):e949. doi:10.1371/ journal.pntd.0000949

15. Amarir F, Mansouri BE, Fellah H, Sebti F, Mohammed L, Handali S, et al. National Serologic Survey of Haematobium Schistosomiasis in Morocco: Evidence for elimination. Am J Trop Med Hyg. 2011;84(1): 15-9.

16. Tosswill JHC, Ridley DS. An evaluation of the ELISA for schistosomiasis in a hospital population. Trans Royal Soc Trop Med Hyg. 1986;80(3):435-8.

17. Teixeira CF, Neuhauss E, Ben R, Romanzini J, Graeff-Teixeira C. Detection of Schistosoma mansoni eggs in feces through their interaction with paramagnetic beads in a magnetic field. PLoS Negl Trop Dis. 2007;1(2):e73. Doi: 10.1371/journal.pntd.0000073

18. Favero, V, Candido RF, Verissimo, CM, Jones M, St. Pierre T, Lindholz $\mathrm{C}$, et al. Optimization of the Helmintex method for schistosomiasis diagnosis. Exp Parasitol. 2017;177:28-34. Doi:10.1016/j. exppara.2017.04.001

19. Souza RP, Favero V, Pascoal VF, Lindholz C, Bittencourt HR, GraeffTeixeira C. Criteria for identification of Schistosoma mansoni eggs in faecal sediments prepared with the Helmintex method and stained by ninhydrin. Mem Inst Oswaldo Cruz. 2019;114:e180529.

20. Stothard JR, Stanton MC, Bustinduy AL, Sousa-Figueiredo JC, van Dam GJ, Betson M, et al. Diagnostics for schistosomiasis in Africa and Arabia: a review of present options in control and future needs for elimination. Parasitology. 2014;141(14):1947-61. doi:10.1017/S0031182014001152

21. Colley DG, King CH, Kittur N, Ramzy RMR, Secor WE, FredericksJames M, et al. Evaluation, Validation, and Recognition of the Pointof-Care Circulating Cathodic Antigen, Urine-Based Assay for Mapping Schistosoma mansoni Infections. Am J Trop Med Hyg. 2020;103(1 Suppl):42-9. Available online, 18 June 2020: Doi 10.4269/ajtmh.19-078 $\overline{8}$ 
22. Siqueira LMV, Couto FFB, Taboada D, Oliveira AA, Carneiro NFF, Oliveira E, et al. Performance of POC-CCA in diagnosis of schistosomiasis mansoni in individuals with low parasite burden. Rev Soc Bras Med Trop. 2016;49(3):341-7. Doi: 10.1590/0037-8682-00702016

23. Peralta JM, Cavalcanti MG. Is POC CCA a truly reliable test for schistosomiasis diagnosis in low endemic areas? The trace results controversy. PLoS Negl Trop Dis. 2018;12(11):e0006813. Doi 10.1371/ journal. pntd.0006813.

24. Lindholz CG, Favero V, Verissimo CM, Candido RRF, Souza RP, Santos RR, et al. Study of diagnostic accuracy of Helmintex, KatoKatz, and POC-CCA methods for diagnosing intestinal schistosomiasis in Candeal, a low intensity transmission area in northeastern Brazil. PLoS Negl Trop Dis. 2018;12(3):e0006274. Doi: org/10.1371/journal. pntd.0006274.

25. Grenfell RFQ, Pedrosa ML, Couto FFB, Almeida A, Coelho PMZ, Katz N. Suitability of commercially available POC-CCA tests for schistosomiasis: Considerations for efficiency, reproducibility and decisionmaking criteria for field application in areas of low endemicity. J Immunol Methods. 2019;472:1-6.

26. van Dam GJ, Wichers JH, Ferreira TM, Ghati D, van Amerongen A, Deelder AM. Diagnosis of schistosomiasis by reagent strip test for detection of circulating cathodic antigen. J Clin Microbiol. 2004;42(12):5458-61.
27. Colley DG, Binder S, Campbell C, King CH, Tchuem Tchuente LA, N'Goran EK, et al. A five-country evaluation of a point-ofcare circulating cathodic antigen urine assay for the prevalence of Schistosoma mansoni. Am J Trop Med Hyg. 2013;88(3):426-32.

28. Mwinzi PNM, Kittur N, Ochola E, Cooper PJ, Campbell Jr CH, King $\mathrm{CH}$, et al. Additional Evaluation of the Point-of-Contact Circulating Cathodic Antigen Assay for Schistosoma mansoni Infection. Front Public Health. 2015;3:48.

29. Coelho PMZ, Siqueira LMV, Grenfell RFQ, Almeida NBF, Katz N, Almeida A, et al. Improvement of POC-CCA Interpretation by Using Lyophilization of Urine from Patients with Schistosoma mansoni Low Worm Burden: Towards an Elimination of Doubts about the Concept of Trace. PloS Neg1 Trop Dis. 2016;10(6):e0004778. doi:10.1371/ journal. pntd.0004778

30. Viana AG, Gazzinelli-Guimarães PH, Castro VN, Santos YLO, Ruas ACL, Bezerra FSM, et al. Discrepancy between batches and impact on the sensitivity of point-of-care circulating cathodic antigen tests for Schistosoma mansoni infection. Acta Trop. 2019;197:e105049. Doi. org/10.1016/j.actatropica.2019.105049.

31. Zoni AC, Catala' L, Ault SK. Schistosomiasis Prevalence and Intensity of Infection in Latin America and the Caribbean Countries, 1942-2014: A Systematic Review in the Context of a Regional Elimination Goal. PLoS Negl Trop Dis. 2016;10(3):e0004493. doi.org/10.1371/journal. pntd.0004493. 